\title{
USING OF INDICATORS FOR ENVIRONMENTAL IMPACT ASSESSMENT IN LATVIA AND NECESSITY FOR INDICATORS VALIDATION
}

\author{
Liga Lieplapa, Dagnija Blumberga \\ RigaTechnical university, Institute of Energy Systems and Environment \\ Kronvalda boulv.1, Riga, LV1005, \\ E-mail: liga.lieplapa@rtu.lv; dagnija.blumberga@rtu.lv
}

\begin{abstract}
The EIA procedure in Latvia as it's known today was implemented by the law „On environmental impact assessment" in 1998. The quantity assessment of expected environmental impact is provided by indicators giving the highest impartiality in this process. The choice of indicators and their approval in EIA projects in Latvia have not received the right attention, the issue is left upon the EIA performers. The problematic issues on necessity of indicator selection and validation are dealt with in the article. 39 environmental indicators were selected for EIA of motor road projects, with the evaluation of their significance and essence, as well as the analysis $f$ application of these indicators in 14 reports concerning EIA of motor road projects. The results revealed the existing problems of indicator application and proved the assumption that there is no common indicator system for the assessment of impact of similar economic projects, proving the necessity of indicator validation to ensure good quality of assessment.
\end{abstract}

Keywords: environmental impact assessment, indicators, validation.

\section{Introduction}

Environmental impact assessment includes several generally approved good practice elements, for example, application of legislative acts, several alternatives [1] and credible forecasting models [2], which can be used as quality indicators in environmental impact assessment. While accumulating experience in EIA, several EIA methods have been worked and adopted, such as data matrix, control lists, networking methods, method of hierarchical analysis, rapid impact assessment matrix (RIAM), expert methodology and others $[3,4]$. Irrespective of methods chosen for particular case of EIA, different indicators or the experience of experts are used in assessment. As pointed out by Van der Werf H.M.G. and Petit J. [5], if only it is possible, the indicators must define the limit values, which in ideal case would be based scientific grounds.

According to formulation of Garrido J. and Requenavides I. [6], the environmental indicator is an element which provides information on condition of environment or close to it. The definition of environmental indicator is incorporated into Latvian legislation and it states that environmental indicators or indices are established reference system into which the environmental condition is assessed. Environmental indicators must be understandable, easily measurable, must clearly reflect the changes in environmental setting [7]. These allow forecast the planned impacts of the project, the environmental quality changes and resource consumption. Still, the indicators are only one of the generally approved sources of assessment of particular theme or problem [8]. The characteristics of indicators have been defined in many research works and literature sources $[9,10,11]$ and these are following:

- quantity values, credible and available,

- easily understandable and politically significant [important],

- showing whether progress has been achieved,

- these are to be verified, comparable, expressed by concrete and standard measurements,

- allow forecasting processes,

- without mutual duplication,

- necessary for users, 
- $\quad$ sensitive to changes,

- in future forecasts, easily combined with socio-economic scenarios,

- allow comparing the results among countries, are scientifically correct (or precise).

Environmental indicators are chosen for each goal or problem in particular sphere. The few most characteristic indicators are selected from the wider scope of indicators which describe the concrete sphere or situation in the best way. For one sphere of environment, for instance, biological diversity, it is recommended to select not more than 2 - 4 indicators [12].

Environmental indicators are important source for policy makers and are helpful in decision making, as well as in the process of monitoring and assessment since they can provide information on complicated issues in quite comprehensible manner [13]. However, it is big challenge to determine which of the indicators of particular sphere are simple enough to be effectively examined and modeled.

According to Cloquell-Ballester V.A. a.o. [14], the quantity assessment of environmental impact is generally carried out which is based on 2 different strategies. The first one is based on the direct quantification of experts' evaluation by using the figure scales. The assessments arising from this approach which are expressed by figures are weighted and summarized and the experts' opinions are the only reference. Therefore, the assessment result is completely Dependant on experts' knowledge, experience and objectivity. Such strategy of environmental impact assessment is also used in Latvia. As the EIA is carried out mainly on contractual basis, the result of EIA is based on independence of experts in the process of EIA. Such assessment strategy is actually in compliance with quality assessment, based on experts' evaluation. Still, as pointed out by Joa o E. [15], the inclusion of qualified EIA expert evaluation is important, since the experts' opinion is one of the most common methods of EIA. In Latvia, the initiator of planned activity is responsible for the preparation of EIA report which allows for carrying out EIA by the initiators of planned activity themselves therefore, in some cases, it can still theoretically present the risk of impartiality or complete lack of assessment. In fact, the indicator selection for EIA is left upon the choice of assessment performer (not always being the experts in particular sphere). The fact that such contractual relations can have adverse effect on credibility of research results are likewise approved by other authors [14].

The other assessment strategy, according to Cloquell-Ballester V.A. a.o. authors [14] is to quantify the impacts by using indicators, considering the difference in environmental quality between „project implementation" and "discontinuation of project or zero-alternative" situations. This strategy is attractive because it allows carrying out verifiable assessment. Therefore, considering the EIA performers and interested parties, in the process of assessment of social and environmental impact, these indicators are validated and approved.

Still, as it is pointed out by Cloquell-Ballester V.A. [14], it is hard to create universal and detailed list of validated indicators, because: a) there can be difference in project land area characteristics, b) lack of data about particular area, c) previously approved indicators might be outdated. The environmental impact assessment must be of multi-disciplinary approach [16]. It means that EIA working party must be represented by experts of different branches, because no person can be expert in all of the areas, including technical ones. In order to carry out the impact assessment of particular activity, EIA working team must select the required and characteristic indicators [14]. The easiest way is to select such indicators that are accepted by scientific and professional circles, examining the possibility of their application, to improve or define the new indicators. The values of indicators must be comparable to real data but as their modes are determined by experts, the assessment is more impartial. The lack of indicator validation or approval can cause adverse reference on the quality of assessment of social and environmental impact, usefulness and credibility, i.e., discredit or question the results of EIA. The necessity of approved indicator system is greater in those countries where the EIA related costs are covered by initiator of planned activity [14], as it is also in Latvia. 


\section{Materials and methods}

The aim of this research is to select environmental indicators for particular object group - i.e., motorway projects and to assess their significance in the context of Latvia. The results obtained will serve as the basis for further research by choosing and adopting into practice indicator validation methods. The hypothesis has been brought forward that the environmental impact assessment of similar projects of economic activities (ex. motorway projects) carried out according to common system of environmental indicators improve the quality of EIA report and reduces influence of subjectivity.

The expert methodology has been used in research, the selecting of indicators due to experience and assumptions. The authors of research summarized indicators that are important for motorway projects, based on the reports of EIA for motorways, their experience and environmental indicators prescribed in literature sources. Not more than 6 indicators were selected for each concrete factor of environmental sphere (air, water, nature, etc.) which characterize the possible impact from motorways. The value in the scale of their significance from 0 to 5 was assigned to each indicator. The description of value significance is presented in Table 1. The assessment of significance of the selected indicators is carried out based on the experience of experts and evaluation of EIA reports of 14 motorway projects, including publications about foreign experience with respect to motorway impact on environment.

Table 1.

The evaluation scale of indicator significance

\begin{tabular}{|c|c|}
\hline Numerical valuation & Mutual valuation \\
\hline 0 & insignificant \\
\hline 1 & negligible significant \\
\hline 2 & low significant \\
\hline 3 & Enough significant \\
\hline 4 & significant \\
\hline 5 & very important \\
\hline
\end{tabular}

After that the significance of each indicator was determined according to the value scale from -2 till +2 , where " -2 " - means insignificant and " +2 " - is significant. Other significant values were not singled out at this stage of research, following the assumption that if the indicator is not included in the assessment process or is not regulated by the law, then, on the national level it can be considered insignificant. At this stage of research, the significance is not valued according to whether or not the particular indicator is included in EIA reports, but following the principal approach.

Analyzing EIA reports, the task was set to determine the application of selected indicators in numerical way, to find out unanimity of experts' opinions in selection of indicators and whether or not there is a need for validation.

The comparison of importance and significance of indicators provides the possibility to evaluate the weakest points in practical phase of EIA, so that the outcome would not be formal but helpful for decision makers and those bringing the project into effect, as well as for supervising institutions and definitely for public interest on the whole.

\section{Results and discussion}

The environmental impact of linear infrastructure such as motorways, must be assessed carefully and in responsible manner since motorway is long-lasting object whose building and reconstruction cause irreversible changes in environment, upon affected territories, causing the barrier effect in environment, as well as promoting the economic development of particular region, which, in turn, can result again in additional load on environment. On the whole, 39 environmental indicators were evaluated, as being the most characteristic for impact of motorways on environment (Fig.1.). 


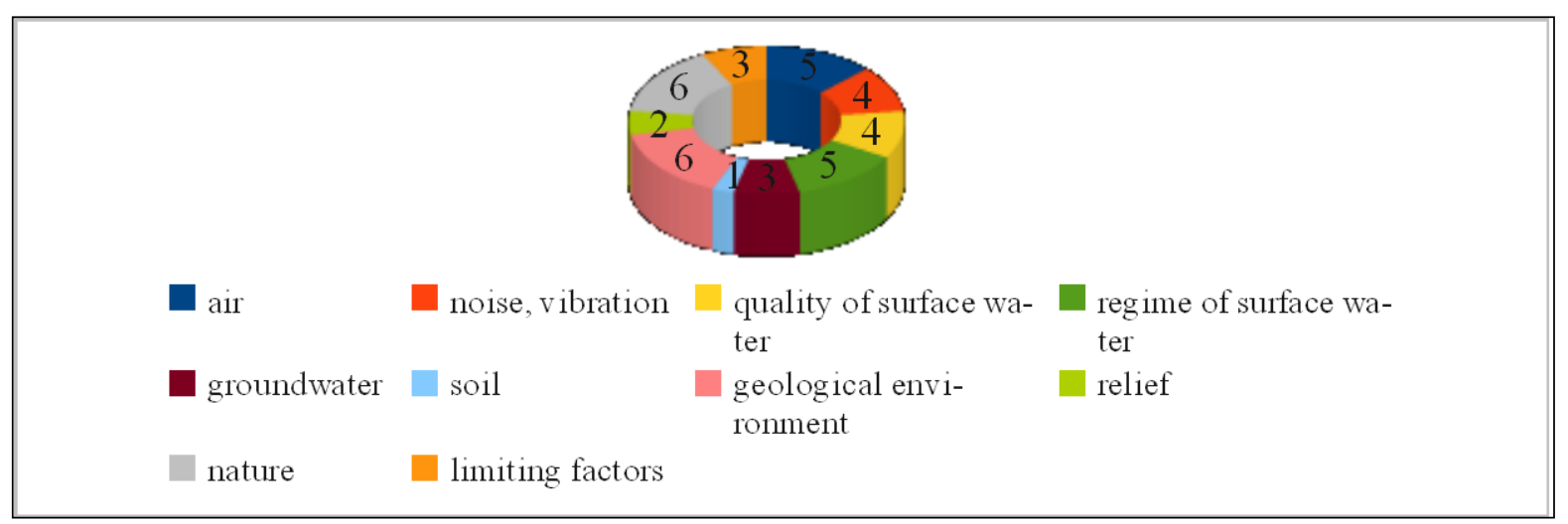

\section{Fig. 1. The selection of environmental indicators EIA of motorway projects (number of indicators for each of the environmental factors)}

The results of indicator significance are presented in Fig.2. and they show that many of indicators (13 out 39 ) which have received high evaluation grades (4 and 5 points) are not now significant on the national level.

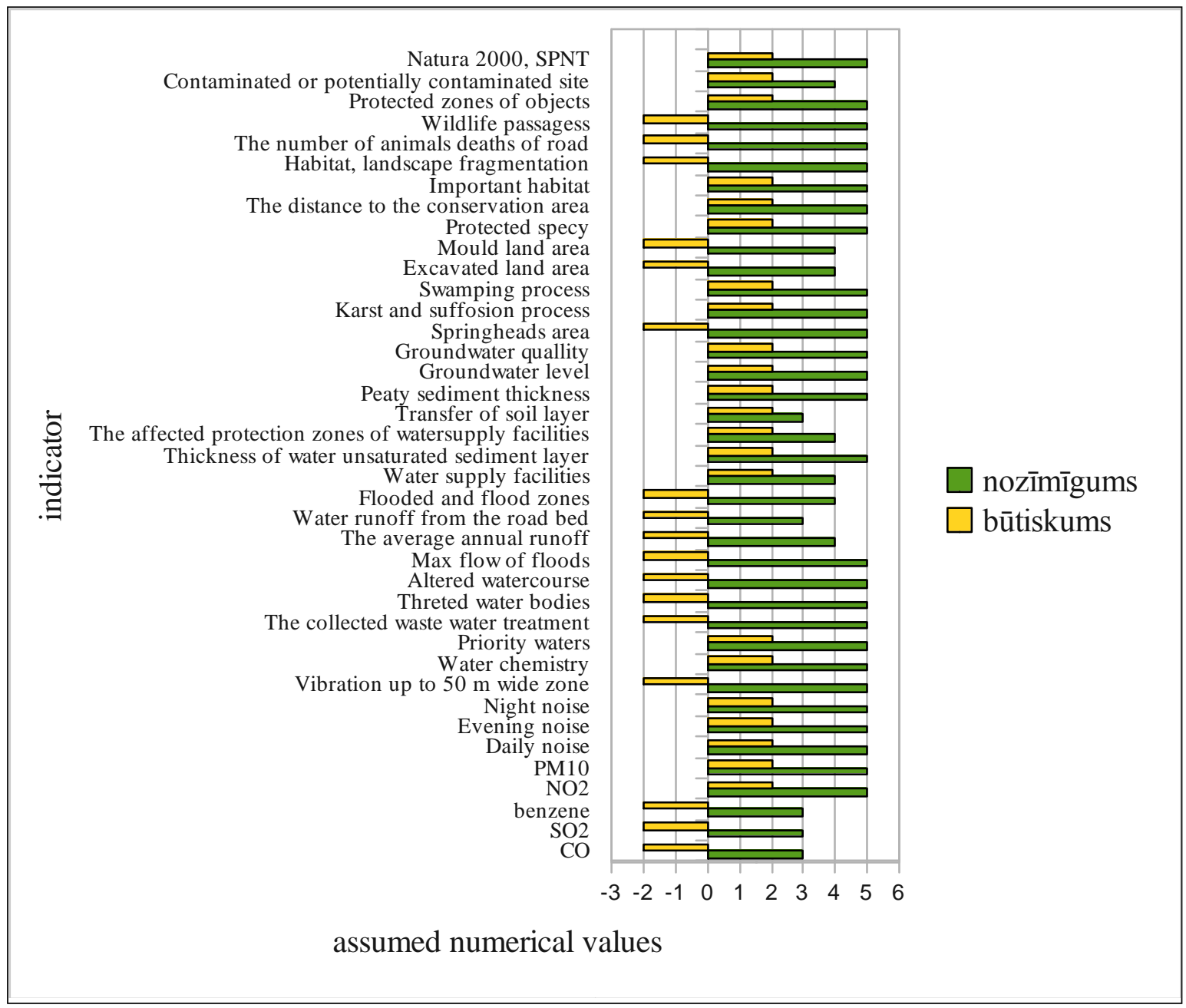

Fig.2. Environmental indicator assessment according to experts' methodology

The significance in this case was evaluated according to the content of EIA report, the requirements for the issued programs of carrying out EIA of motorway projects and the indicators and limit values stipulated by the legislative acts, as well as following concrete 
criteria- whether or not the concrete answer and numerical evaluation is given for the indicator in question. For example, the indicator called "natural wildlife passages" (measured in numbers) is mentioned in largest part of EIA reports, but actually there is no concrete data where and how many such crossing (transfer) places exist on a planned motorway route and what kind of animals use them. Therefore, the significance of this indicator at the present context of EIA in this research was considered as being undervalued or insignificant (-2) on the national level.

During the course of research, the practical application of 39 environmental indicators in EIA reports concerning motorway projects was analyzed in greater detail. Indicators can be divided into 2 groups: a) those, whose limit values are determined by legislative documents of Republic of Latvia, b) which are not determined by the law and are put forward by experts. Besides, the application of concrete indicators also from the first group is chosen by experts (for example, PM10 and $\mathrm{NO}_{2}$ are mainly chosen for the forecast of changes in air quality).

The analysis of indicator application within the framework of research was encumbered by several factors: a) the analyzable indicators are not formulated in large number of cases, b) quite often no numerical values, expressed in measuring units are provided, assessment is given in wording (is, isn't and etc.), c) indicators are not compared before (the current status) and after the project implementation (anticipated condition), as well as d) indicators are not compared among different project alternatives. The above mentioned problems are more particularly evident in EIA reports during the last years.

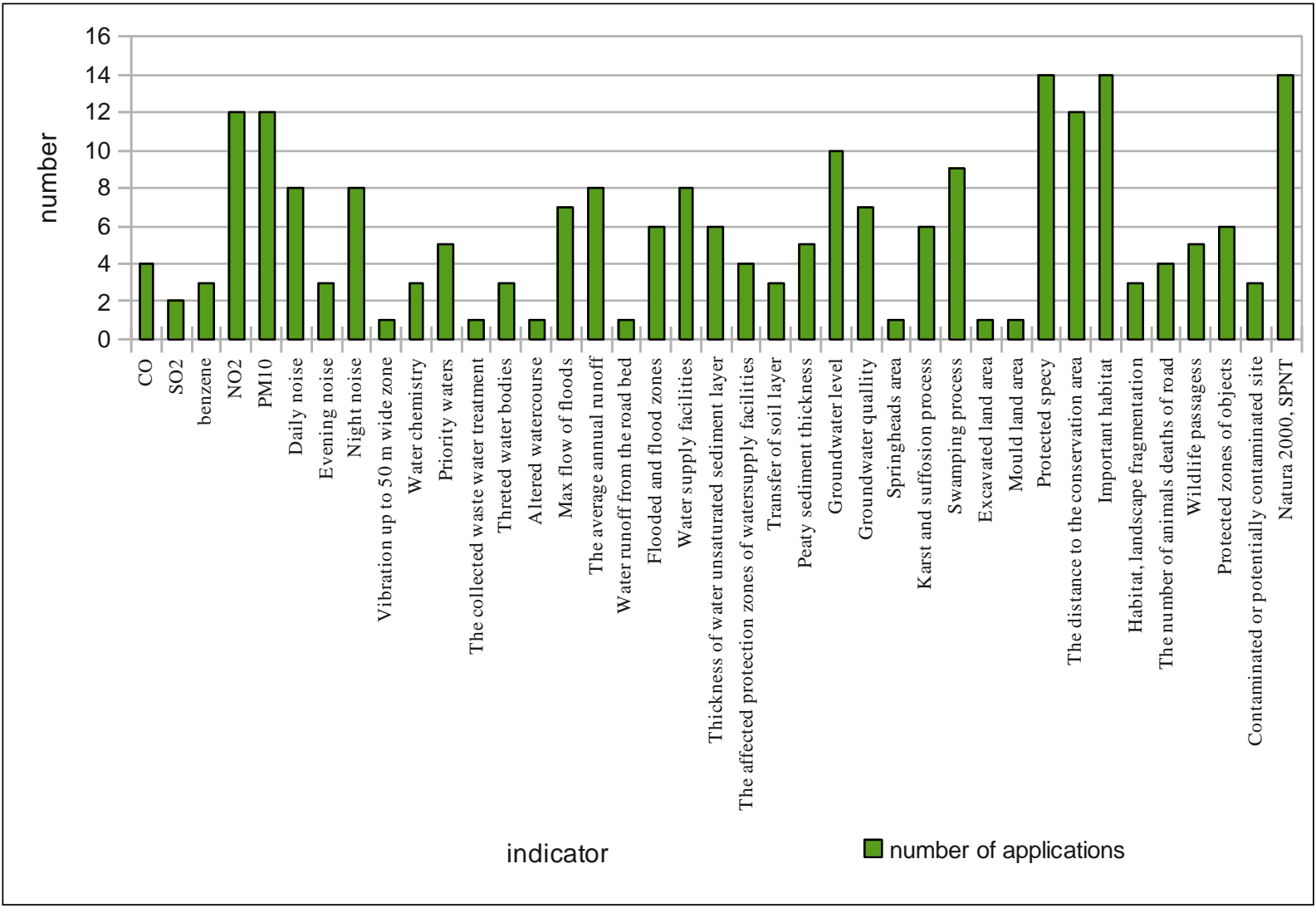

Fig.3. The application of environmental indicators in EIA reports for motorway projects

Therefore, the indicator within this research is considered to have been applied only when the evaluation was provided for it (numerical or descriptive). Results of application analysis (Fig.3) reflect the fairness of hypothesis that unified indicator system for similar projects of economic activity such as environmental impact assessment of motorway projects will improve the quality of report and reduce the subjectivity. From the Fig. 3, it follows that $36 \%$ or 14 out of 39 of the analyzed indicators in research were used only in half ( 7 out of 14) of 
EIA reports. Furthermore, the evaluation of several environmental factors in some cases of EIA is not based on indicator analysis. Consequently, EIA are more of descriptive nature and doesn't provide unambiguous notion about possible impacts that doesn't relieve the decision making.

The results of research show that the experts' evaluation method is actually used in EIA reports and selection of environmental indicators is left to the discretion of EIA performers. Finally, it can reflect upon the quality of impact assessment of planned activity, not excluding subjectivity and superfluity. This situation clearly points out the necessity of approval of indicators and bringing forward the criteria.

\section{Conclusions}

Any kind of economical activity by people causes environmental impact, both positive and negative, therefore it is important to assess the significance of the impact in adequate and impartial manner. The impartiality can be ensured by environmental indicators recognized by experts in particular areas. Besides, it would be preferable to use common indicator system for assessment of possible impact of each group of economic activities since the manner of impact of similar economic activities upon the same environmental factor (for example, surface water quality, air quality, eco-system quality, etc.) will be more or less alike, but the intensity and character of impact are correlated according to specific local conditions and /or applied technology. This approach would allow increase the credibility of impartiality, the assessment would be comparable, easier perceivable for public and decision makers.

The research results show that the quality of EIA in Latvia depends on qualifications and professional approach of EIA performers of this process, i.e., the choice or ,not choosing” of indicators is left to discretion of experts. For the characteristics of one and the same indicator different approaches are used - ignorant, descriptive, formal or numerically evaluated that can affect the quality of EIA reports and public trust in impartiality of EIA.

Such approach doesn't provide or reduce the possibility to compare and evaluate project alternatives according to such an indicator, besides it can not be used as reference point for the status control during project implementation and of operational time. Once again, it proves the significance of indicator selection for qualitative EIA. Many literature sources point out the necessity and possibility of approving the indicators in order to avoid subjectivity and superfluity in impact assessment. The results of this research work prove the necessity of indicator validation also in Latvia.

\section{References}

1. Steinemann A., Improving alternatives for environmental impact assessment. Environmental Impact Assessment Review Volume 21, Issue 1 [2001], Pages 3-21.

2. Androulidakis I., Karakassis I., Evaluation of the EIA system performance in Greece, using quality indicators. Environmental Impact Assessment Review 26 [2006] p. 242- 256.

3. Discoli C.A., Urban environmental impact matrices development: assessment indices incorporation. Building and Environment 40 [2005] 915-928.

4. Wang Y.-M., Yang J.-B., Xu D.-L., Environmental impact assessment using the evidential reasoning approach. European Journal of Operational Research 174 [2006] 1885-1913.

5. Van der Werf H.M.G., Petit J., Evaluation of the environmental impact of agriculture at the farm level: a comparison and analysis of 12 indicator-based methods. Agriculture, Ecosystems and Environment 93 [2002] 131-145.

6. Garrido J., Requena I., Proposal of ontology for environmental impact assessment: An application with knowledge mobilization. Expert Systems with Applications 38 [2011] 2462-2472.

7. LR MK noteikumi Nr.175 "Noteikumi par nacionālajiem vides indikatoriem". 24.02.2009., ar grozījumiem 25.05.2010.

8. Latvijas vides indikatoru pārskats 2001. LR VARAM, Latvijas Vides aǵentūra, 2001, 7.lpp.

9. Gupta A.K., Sinha R., Criteria and Indicators of Sustainability: an executive summary. Executive Summary of the Proceedings of the International Training Workshop, "Criteria and Indicators of Sustainability in Rural Development: A Natural Resource Perspective", March 11-13, 1999.

10. B. ten Brink, Biodiversity indicators for the OECD environmental outlook and strategy. A feasibility study. RIVM Report 402001014, 2000. 
Lieplapa L., Blumberga D. USING OF INDICATORS FOR ENVIRONMENTAL IMPACT ASSESSMENT IN LATVIA AND NECESSITY FOR INDICATORS VALIDATION

11. www.epa.gov/indicators/whatIndicator.html

12. Guidelines for Country Studies on Biological Diversity, UNEP, Nairobi [1993].

13. Niemeijer D., de Groot R.S., A conceptual framework for selecting environmental indicator sets. Ecological indicators 8 [2008] 14-25.

14. Cloquell-Ballester V.A., Cloquell-Ballester V.A., Monterde-Diaz R., Santamarina-Siurana M.C., Indicators validation for the improvement of environmental and social impact quantitative assessment. Environmental Impact Assessment Review 26 [2006] 79-105.

15. Joa o E., How scale affects environmental impact assessment. Environmental Impact Assessment Review 22, 2002. p. 289-310.

16. Canter L.W., Interdisciplinary teams in environmental impact assessment. Environmental Impact Assessment Review11 [1991] 375-387.

Anotācija. Ietekmes uz vidi novērtējuma (IVN) procedūra pašreizējā izpratnē Latvijā ir ieviesta 1998. gadā ar likumu "Par ietekmes uz vidi novērtējumu”. Kopš tā laika IVN ir veikts virknei dažādu projektu, tai skaitā, rekonstruējamiem vai no jauna būvējamiem valsts autoceļa posmiem. Paredzèto darbību ietekmju uz vidi kvantitatīvu novērtēšanu nodrošina indikatori, kas sniedz visaugstāko iespējamo objektivitāti šajā novērtējuma procesā. Līdz ar to lèmuma pieņēmēji tiek nodrošināti ar korektu informāciju un novērtējuma rezultātiem. Latvijā indikatoru izvēlei un apstiprināšanai IVN projektos nav pievērsta īpaša uzmanība - jautājums atstāts IVN veicēju zin̄ā. Lai uzlabotu IVN ziņojumu kvalitāti, šajā rakstā tiek diskutēts par problemātiskajiem jautājumiem indikatoru izvēlē un indikatoru apstiprināšanas (validēšanas) nepieciešamību. Tika atlasīti 39 vides indikatori autoceļu projektu IVN, novērtēts to nozīmīgums un būtiskums, kā arī veikta šo indikatoru pielietojuma analīze 14 autoceļu projektu IVN ziņojumos. Rezultāti atklāja esošās problēmas indikatoru pielietošanā un apstiprināja pieñèmumu, ka nav vienotas indikatoru sistēmas līdzīgu saimniecisku projektu ietekmju novērtēšanā, pierādīja nepieciešamību indikatoru validēšanai, lai nodrošinātu labu novērtējuma kvalitāti. 